\title{
Mind Mapping Assisted Talking Stick Learning Model on Speaking Skills
}

\author{
Putu Agus Putra Sastrawan \\ Program Studi PGSD, Universitas Pendidikan Ganesha, Singaraja, Indonesia \\ email: agussastrawan996@gmail.com \\ Dewa Nyoman Sudana \\ Program Studi PGSD, Universitas Pendidikan Ganesha, Singaraja, Indonesia \\ email: sudananyoman512@gmail.com
}

\section{A R T I C L E I N F O Article history: \\ 1 Agustus 2020 Received in revised form \\ 20 September 2020 \\ Accepted 10 November 2020 \\ Available online 20 \\ November 2020

\begin{tabular}{lc}
\hline Kata Kunci: & \\
Talking $\quad$ Stick, & Mind \\
Mapping, Berbicara &
\end{tabular} \\ Keywords: \\ Talking Stick; Mind Mappin; \\ Speaking.}

\begin{abstract}
A B S T R A K
Rendahnya keterampilan berbicara siswa dapat mengakibatkan proses pembelajaran kurang aktif. Hal tersebut dapat dibuktikan dengan belum sesuainya pelaksanaan pembelajaran mengenai keterampilan berbicara dengan apa yang diharapkan. Penelitian ini bertujuan untuk mengkaji model pembelajaran talking stick berbantuan mind mapping terhadap keterampilan berbicara siswa kelas V. Penelitian ini merupakan penelitian quasi eksperiment (eksperimen semu) dengan menggunakan rancangan nonequivalent post-test only control grup design. Jumlah populasi dalam penelitian ini adalah 125 siswa, dan sampel penelitian ini berjumlah 45 siswa yang ditentukan dengan teknik simple random sampling. Data keterampilan berbicara siswa dikumpulkan dengan menggunakan metode non-tes berupa penilaian unjuk kerja. Data keterampilan berbicara dianalisis menggunakan statistik deskriptif dan inferensial dengan analisis ujit. Berdasarkan hasil analisis, rata-rata kelompok eksperimen adalah 77,14 sedangkan kelompok kontrol adalah 70,625 dan $\left(t_{\text {hitung }}=2,682>t_{\text {tabel }}=1,68107\right)$. Hasil penelitian ini menunjukkan bahwa terdapat pengaruh yang signifikan model pembelajaran talking stick berbantuan mind mapping terhadap keterampilan berbicara siswa kelas $\mathrm{V}$.
\end{abstract} Berdasarkan hasil temuan tersebut, dapat disimpulkan bahwa model pembelajaran talking stick berbantuan mind mapping berpengaruh terhadap keterampilan berbicara siswa kelas $\mathrm{V}$.

\section{Introduction}

Learning is a process of interaction between students and learning components such as teachers, media, teaching materials, etc. Good learning can encourage students to discover and transform the information they have obtained with information already in students' memories (Ariani, 2017; Sumiyati, 2017). The teacher's role is to design learning and form a learning atmosphere. Competent teachers will be better able to create an effective learning environment to improve students' speaking ability (Mursalin et al., 2017). Good communication is needed between students and teachers and students and students to make learning effective. Communication is divided into two, oral and written communication. Good speaking skills are needed. Speaking skill is a skill possessed by individuals to participate with their environment To carry out good oral communication, of course (Lailiyah \& Wulansari, 2017; St, 2020). Students are expected to communicate well (Agung Prasetyo, 2019; Sari et al., 2017; Suarjani et al., 2013). Students can share information or knowledge and implement one of the 4C skills expected in the 2013 curriculum. 
However, the facts found in the field, in the implementation of Indonesian language learning, especially regarding speaking skills, have not matched what was expected. Based on the results of observations on 24-25 October 2019 in the fifth grade of SD Gugus I, Kecamatan Gerokgak, Kabupaten Buleleng, 2019/2020 Academic Year. Students were hesitant to express their opinions directly. Students were less active in asking or answering during discussions. When answering questions orally, the student does not use effective sentences. Students seem not focused on listening to the teacher's explanation. The teacher still uses a teacher-centered learning model. The teacher does not use learning media to support the learning process. In addition to conducting observations, interviews were also conducted on October 26, 2019 with fifth-grade elementary school teachers in Gugus I, Gerokgak District, Buleleng Regency, 2019/2020 Academic Year. Based on the interview results, students in conveying information verbally, the pronunciation was less clear. When students are answering questions verbally, they were still stammering or not fluent. Students' speaking skills were low. It could be seen from the lack of student response when the teacher asked questions and when students are asked to express their opinions verbally.

It was also strengthened by recording documents on fifth-grade elementary school students' speaking skill scores in Gugus I, Kecamatan Gerokgak District, Kabupaten Buleleng. Based on the document recording results regarding fifth-grade elementary school students' speaking skill score in Gugus I, Kecamatan Gerokgak, Kabupaten Buleleng, 2019/2020 Academic Year. Of 125 students who reached the minimum completeness criteria were 63 people (50.4\%), while 62 students did not reach the minimum completeness criteria (49.6\%). It means that the difference between students who reach the minimum completeness criteria and those who do not reach the minimum completeness criteria is one person $(0.8 \%)$, so almost half of the students have not reached the minimum completeness criteria.

From the above problems, it is necessary to use models and media to support the learning process in a conducive and active manner. The talking stick learning model is a learning model that can encourage students to have the courage to express their opinions (Anisa, 2020; Sugiantiningsih \& Antara, 2019). With the talking stick learning model, the learning atmosphere becomes conducive, and students become active in participating in the learning process (Lisdayanti et al., 2014; Pour et al., 2018). The advantages of talking sticks are training students to understand the material quickly, testing students' readiness, encouraging students to be more active in learning, and teaching their own opinions, so that students think for themselves what the answers to these questions (Seika Ayuni et al., 2017; Suarjani et al., 2013). Research conducted by (Suhardiana, 2018) The talking stick model is intended to bring out positive emotions and learning attitudes in the teaching and learning process, impacting students' brains' intelligence. Other research conducted by (Sumanto, 2018) stated that the talking stick model could improve critical thinking, creativity, responsibility, self-confidence, and respect for fellow friends because they are interdependent in generating positive responses and forming students independently.

Apart from the talking stick model, the mind mapping model can also solve this problem. Mind mapping is the easiest way to enter information into the brain and retrieve information from the brain (Arsana et al., 2019; Karim, 2018; Muhamad Husni, 2018; Syam \& Ramlah, 2015). Mind mapping media can make it easier for students to recall the information that has been obtained. This method is the most creative and effective way of taking notes, so it can be said that mind mapping maps the minds of the people who make it. With mind mapping in applying the talking stick learning model, it is hoped that it can create conducive and fun learning and improve students' speaking skills so that learning objectives are achieved optimally (Sartono et al., 2018). This study's results are supported by research conducted by (Suparmi et al., 2019). There are differences in writing skills between students taught using the mind mapping method and conventional, both from high and low verbal abilities.

Further research conducted by (Iswanto, 2017) shows that mind mapping techniques can improve science learning outcomes of VIIIE students in the first semester of SMP N 1 Manggis in the 2015/2016 academic year. Research conducted by Nuriani, (2014) states that using the inquiry learning method assisted with the mind mapping approach is more effective than learning using the expository learning method. Research conducted by Suwitri et al., (2013) stated that mind mapping learning assisted by concrete media on the science learning outcomes of fifth-grade students of SD Gugus III Banjar Anyar Kediri.

Innovative learning models were carried out to improve student learning outcomes. It is necessary to conduct a study to know the effect of mind mapping-assisted talking stick learning models on fifth-grade elementary school students' speaking skills in Gugus I, Kecamatan Gerokgak Kabupaten Buleleng, 2019/2020 Academic Year. By conducting this research, it is hoped that it will help students solve problems related to speaking skills. 


\section{Method}

This type of research is a quasi-experiment with a non-equivalent post-test only control group design. The population in this study were all fifth grade students of SD in Gugus I, Kecamatan Gerokgak, Kabupaten Buleleng for the 2019/2020 academic year, which consisted of five schools, SD Negeri 1 Tukadsumaga, SD Negeri 2 Tukadsumaga, SD Negeri 3 Tukadsumaga, SD Negeri 4 Tukadsumaga, and SD Negeri Celukan Bawang. Determination of the sample in this study was carried out by using a simple random sampling technique. The equivalence is tested first with one-way ANOVA to find out that the sample is truly equivalent. The analysis results with ANOVA A at $5 \%$ significant level obtained Fcount <Ftable $(0.06<2.45)$ so that H1 is rejected and $\mathrm{HO}$ is accepted. Based on this analysis results, fifth-grade elementary school students' speaking skills in Gugus I, Gerokgak Subdistrict, Buleleng Regency, Academic Year 2019/2020 are equivalent. After being declared equal, the five classes in Cluster 1, Gerokgak District, Buleleng Regency were given code A for SD Negeri 1 Tukadsumaga, code B for SD Negeri 2 Tukadsumaga, code C for SD Negeri 3 Tukadsumaga, code D for SD Negeri 4 Tukadsumaga, and code E is for SD Negeri Celukan Bawang. Then the sample was taken using the random sampling technique to determine the two classes as the research sample. The fifth grade SD Negeri 4 Tukadsumaga consists of 21 students as the experimental group and the fifth grade SD Negeri 3 Tukadsumaga consisting 24 as the control group. In this study, the method used to collect data was a non-test method with performance assessment instruments. Performance assessment instruments are guided by speaking skills, aspects of pronunciation, word emphasis, sentence effectiveness, and fluency. The data obtained in this study came from the post-test results of students' speaking skills. The data analysis technique used in this research is descriptive statistical analysis and inferential statistics. This study's descriptive statistical analysis included determining the mean, mode, median, variance, and standard deviation scores. Meanwhile, this study's inferential statistical analysis was carried out using the t-test with the polled variance formula to test the hypothesis. Before testing the hypothesis, the data must be normally distributed, and the variance is in a homogeneous group. Therefore, an analysis of the normality and homogeneity test of the data was carried out first. The normality test was performed using the Chi-Square analysis, while the homogeneity test was performed using the Fisher test analysis.

\section{Result and Discussion}

The research data were the students' speaking skill scores, which were obtained through the post-test. The post-test results of speaking skills in the experimental group towards 21 students showed that the highest score was 95 and the lowest score was 60. Meanwhile, the post-test result of speaking skills in the control group of 24 students showed that the highest score was 85 and the lowest score was 55 . The speaking skill data in this study about the mean, median, mode, standard deviation, and variance are presented in Table 1.

Table 1. Description of the Experimental Group and Control Group Speaking Skills Data

\begin{tabular}{lll}
\hline Hasil Analisis & Kelompok Eksperimen & Kelompok Kontrol \\
\hline Mean & 77,14 & 70 \\
Median & 78,1 & 73,25 \\
Modus & 80,5 & 73,5 \\
Standar Deviasi & 9,024 & 7,698 \\
Varians & 81,43 & 59,266 \\
\hline
\end{tabular}

Based on table 1, it is found that the mean score of the experimental group is higher than the control group; the scores (77.14) and (70) indicate this. The experimental group's median score is $(78.1)$ and $(73,25)$ in the control group. The experimental group mode was 80.5, and the control group 73.5. The standard deviation is 9,024 for the experimental class and 7,698 for the control class. The variance was 81.43 for the experimental class and 59.266 for the control class. Based on these results, there are differences in the descriptive test results between the experimental and control classes.

Furthermore, the assumption test includes data normality test and variance homogeneity test. The results of the data distribution normality test in the experimental group obtained the score of $\mathrm{X}_{\text {count }}=3.766<\mathrm{X}_{\text {table }}^{2}=$ 12.692 at the $5 \%$ significance level and $\mathrm{dk}=7-1=6$. It means that $\mathrm{H} 0$ is accepted, meaning that the data distribution of the post-test score of speaking skills of fifth-grade students in the group experiments is normally distributed. While the results obtained in the control group, the score of $\mathrm{X}_{\text {count }}^{2}=2.33<\mathrm{X}_{\text {tabel }}^{2}=12.592$ at the $5 \%$ significance level and $\mathrm{dk}=7-1=6$. It means that $\mathrm{H} 0$ is accepted, meaning that the data distribution of the posttest score of the fifth-grade students in the control group was normally distributed. Furthermore, the variance homogeneity test obtained the score of $\mathrm{F}_{\text {count }}=1.54$ and $\mathrm{F}_{\text {table }}=4.08$ with a significance level of $5 \%$. Thus, the 
$\mathrm{F}_{\text {count }}<\mathrm{F}_{\text {table }}$ score means no difference in variance between the experimental and control groups (homogeneous data variance).

After the assumption test is fulfilled, the hypothesis test is carried out using the t-test with the polled variance formula. The results of the t-test analysis showed that $\mathrm{t}$-count $=2.682$ while the t-table score at the $5 \%$ significant level with degrees of freedom $(n 1+n 2-2)=21+24-2=43$ was 1.68107. Based on $t_{\text {count }}=2.682>$ $\mathrm{t}_{\text {table }}=1.68107$ then $\mathrm{H} 1$ is accepted. Based on the results of the analysis that has been carried out, it can be concluded that, there is a significant influence on the talking stick learning model assisted by mind mapping on the speaking skills of fifth grade elementary school students in Gugus I, Kecamatan Gerokgak, Kabupaten Buleleng, 2019/2020 Academic Year.

The learning process by applying the taking stick learning model allows students to express their opinions directly in front of the class. Students become more active in following the learning process. The talking stick learning model is a learning model that can encourage students during the learning process to have the courage to express their opinions directly (Ivone et al., 2020; Widyastuti, 2018). For example, students are directly involved in the stick game activity, which later determines the students' turn to speak in front of the class according to the learning material. Learning activities involve students discussing with group members related to the learning material being taught. Using the talking stick learning model allows students to express their opinions in front of the class directly. Students express their opinions based on their understanding of the material that has previously been discussed with their group members. Students find it easier to understand the learning material being taught because they have discussed it with group members. Learning that involves peers will reduce anxiety and stress. With being guided, assisted, and given feedback by peers, students will increase self-confidence (Han et al., 2015; Stone et al., 2013). Learning by using the talking stick model has a positive impact on student learning outcomes because students learn actively in the learning process Pranata et al., (2013) which states that the Talking Stick learning model assisted by Crossword Puzzle in Information and Communication Technology (ICT) subjects can improve learning outcomes and get a positive response from students. Research conducted by Dewi et al., (2017) stated that applying the talking stick type of cooperative learning model assisted by the question card media affected the students' competence in social studies knowledge. Antara et al., (2019) stated that the talking stick learning model assisted with newspaper rubrics affected students' speaking skills. So with the talking stick learning model, students will be more active in learning and develop their ability to work together.

In addition to using the talking stick learning model, learning media in mind mapping can also influence students' speaking skills. Learning using the talking stick learning model assisted by mind mapping provides the opportunity for students to package the learning material previously discussed together into the form of mind mapping creatively by developing ideas from each student. Mind mapping can help students think creatively in pouring learning material into mind mapping to receive and deliver learning material that they have understood. Mind mapping is the easiest way to enter information into the brain and retrieve information from the brain (Arsana et al., 2019; Karim, 2018; Muhamad Husni, 2018; Syam \& Ramlah, 2015). Mind mapping media can make it easier for students to recall the information that has been obtained. This method is the most creative and effective way of taking notes, so it can be said that mind mapping maps the minds of the people who make it. With mind mapping in applying the talking stick learning model, it is hoped that it can create conducive and fun learning and improve students' speaking skills to achieve optimal learning objectives. (Sartono et al., 2018).

The talking stick learning model assisted with mind mapping can help students gain a direct learning experience by inviting students to play. In this case, the game is the game of passing the stick according to the steps (syntax) of the talking stick learning model. With the element of play, students do not feel bored to participate in the learning process so that the class atmosphere becomes conducive. The talking stick learning model is a learning model that can create a pleasant learning situation for students because, in the application of the talking stick learning model, there is an element of play that can make students happy so that students do not feel bored and bored in participating in the learning process (Puspitawangi et al., 2017; Seika et al., 2017). During the learning process, students also study with their respective group members. In groups, students are required to discuss later to make mind mapping. Groups are formed by teachers heterogeneously. In heterogeneous groups, all students can understand the material and motivate each other in learning. Teachers will find it easier to organize the course of learning so that learning objectives are achieved. Learning in groups will allow students to exchange information and help each other or understand learning materials that cannot be completed independently.

Students can motivate each other to learn. The application of the mind mapping-assisted talking stick learning model requires a lot of time in its implementation. The timing rules can circumvent this in stick games. If students are not ready when they have their turn to present the mind mapping, then the stick game will be continued until a student gets the next turn. By applying the talking stick learning model assisted by mind mapping, students become more enthusiastic in participating in learning and faster in understanding the material and test students' readiness to issue opinions about the material that has been previously studied. Students find it 
easier to express their opinions because they are assisted by mind mapping made previously. If students can express their opinions with mind mapping, students become trained and speak so that students' speaking skills improve.

\section{Conclusion}

Based on the research and discussion result, it can be concluded that there is a significant influence on the talking stick learning model assisted by mind mapping on fifth-grade elementary school students' speaking skills in Gugus I, Kecamatan Gerokgak, Kabupaten Buleleng, Academic Year 2019/2020. It is shown by the results of hypothesis testing using the t-test with the results of $t_{\text {hitung }}=2,682>t_{\text {tabel }}=1,68107$ at a significant level of 5\%, so H0 is rejected. The experimental group students' average speaking skills were 77.14 greater than the control group students' speaking skills of 70.625 .

\section{References}

Agung Prasetyo, D. A. A. S. (2019). Pengaruh Teknik Bermain Peran Terhadap Keterampilan Berbicara. DEIKSIS, 10(02), 85-91. https://doi.org/10.31227/osf.io/5847h

Anisa, S. (2020). Model Pembelajaran Talking Stick Dalam Meningkatkan Keterampilan Mengkomunikasikan Pembelajaran Sejarah Bagi Peserta Didik. https://doi.org/10.31219/osf.io/2f7jk

Antara, I. N. P., Kristiantari, M. G. R., \& Suadnyana, I. N. (2019). Pengaruh Model Pembelajaran Talking Stick Berbantuan Rubrik Surat Kabar Terhadap Keterampilan Berbicara. International Journal of Elementary Education., 3(4), 423-430. https://doi.org/http://dx.doi.org/10.23887/ijee.v3i4.21315

Ariani, T. (2017). Pembelajaran Kooperatif Tipe Team Assisted Individualization (TAI): Dampak Terhadap Hasil Belajar Fisika Siswa. Jurnal Ilmiah Pendidikan Fisika Al-Biruni, 6(2), 169. https://doi.org/10.24042/jipfalbiruni.v6i2.1802

Arsana, I. K., Suarjana, M., \& Arini, N. W. (2019). Pengaruh Penggunaan Mind Mapping berbantuan Alat Peraga Tangga Garis Bilangan terhadap Hasil Belajar Matematika. International Journal of Elementary Education, 3(2), 99-107. https://doi.org/http://dx.doi.org/10.23887/ijee.v3i2.18511

Dewi, N. P. D. A., Wiyasa, I. K. N., \& Asri, I. G. A. A. S. (2017). Pengaruh Model Kooperatif Talking Stick Berbantu Question Card terhadap Kompetensi Pengetahuan IPS Siswa kelas IV. Mimbar PGSD, 5(2). https://doi.org/http://dx.doi.org/10.23887/jjpgsd.v5i2.10790

Han, J.-S., Baek, H. C., \& Jeong, A.-S. (2015). The Effects of Psychiatric Nursing Simulation on Anxiety and Self-confidence about Clinical Placement of Nursing Students. Journal of the Korea AcademiaIndustrial Cooperation Society, 16(11), 7812-7819. https://doi.org/10.5762/kais.2015.16.11.7812

Iswanto, P. R. (2017). Mind Map Learning Model to Improve The Activities And The Learning Outcomes In The Competency Of Electrical System And Instrument Of XI Grade Student Of The Motorcycle Engineering Program In SMK DIPONEGORO Depok Sleman. 92 Jurnal Taman Vokasi, 5(1), 92-105. https://doi.org/http://dx.doi.org/10.30738/jtv.v5i1.1541

Ivone, F. M., Mukminatien, N., \& Tresnadewi, S. (2020). Blended Learning Untuk Penguatan Kompetensi. Jurnal Graha Pengabdian, 2, 18-26.

Karim, A. (2018). Efektivitas Penggunaan Metode Mind Map Pada Pelatihan Pengembangan Penguasaan Materi Pembelajaran. IJTIMAIYA: Journal of Social Science Teaching, 1(1). https://doi.org/10.21043/ji.v1i1.3098

Lailiyah, N., \& Wulansari, W. (2017). Peningkatan Keterampilan Berbicara Melalui Metode Diskusi Kelompok Model Tanam Paksa Siswa Kelas X Pemasaran 1 SMK PGRI 2 Kediri. Jurnal Pendidikan (Teori Dan Praktik), 1(2), 166. https://doi.org/10.26740/jp.v1n2.p166-173

Lisdayanti, N. P., Ardana, I. K., \& Suryaabadi, I. B. G. (2014). Pengaruh Model Pembelajaran Kooperatif Talking Stick Berbantuan Media Gambar Terhadap Hasil Belajar IPA Siswa Kelas V Sd Gugus 4 Baturiti. Journal Mimbar PGSD Universitas Pendidikan Ganesha Jurusan PGSD, 2(1). https://doi.org/http://dx.doi.org/10.23887/jjpgsd.v2i1.1962

Muhamad Husni, Z. (2018). Memahami Konsep Pemikiran Mind Map Tony Buzan (1970) Dalam Realitas Kehidupan Belajar Anak. Al-Ibrahl, http://ejournal.stital.ac.id/index.php/alibrah/article/download/45/38 
Mursalin, Sulaiman, \& Nurmasyitah. (2017). Peran Guru Dalam Pelaksanaan Manajemen Kelas Di Gugus Bungong Seulanga kecamatan Syiah Kualakota Banda Aceh. Jurnal Ilmiah Pendidikan Guru Sekolah Dasar, 2(1), 105-114.

Nuriani, N. R. (2014). Efektifitas Penggunaan Metode Pembelajaran Inquiry Berbantuan Pendekatan Mind Mapping terhadap Kemampuan Berpikir Kritis Matematika. Jurnal Derivat, 1(1), 8-18. https://doi.org/https://doi.org/10.31316/j.derivat.v4i1.233

Pour, A. N., Herayanti, L., \& Sukroyanti, B. A. (2018). Pengaruh Model Pembelajaran Talking Stick terhadap Keaktifan Belajar Siswa. Jurnal Penelitian Dan Pengkajian Ilmu Pendidikan: E-Saintika, 2(1), 36. https://doi.org/10.36312/e-saintika.v2i1.111

Pranata, P. A., Sudirtha, I. G., \& Wahyuni, D. S. (2013). Penerapan Model Pembelajaran Kooperatif Tipe Talking Stick Berbantuan Crossword Puzzle Untuk Meningkatkan Hasil Belajar Teknologi Informasi dan Komunikasi Siswa Kelas VII 2. MIMBAR PGSD Undiksha, 2(4). https://doi.org/http://dx.doi.org/10.23887/karmapati.v2i4.19675

Puspitawangi, K. R., Wibawa, I. M. C., \& Pudjawan, K. (2017). Pengaruh Model Pembelajaran Kooperatif Tipe Talking Stick Berbantuan Media Audio Visual Terhadap Hasil Belajar Ips. MIMBAR PGSD Undiksha, 5(2). https://ejournal.undiksha.ac.id/index.php/JJPGSD/article/download/6957/4747

Sari, N. P. A., Kristiantari, M. G. R., \& Asri, I. G. A. A. S. (2017). Pengaruh Model Pembelajaran Literasi sebagai Budaya Sekolah terhadap Pengusaan Kompetensi Pengetahuan IPS Siswa Kelas V. E-Journal PGSD, 5(2), 1-10. https://doi.org/http://dx.doi.org/10.23887/jjpgsd.v5i2.10761

Sartono, N., Komala, R., \& Dumayanti, H. (2018). Pengaruh Penerapan Model Reciprocal Teaching Terintegrasi Mind Mapping Terhadap Pemahaman Konsep Siswa Pada Materi Filum Arthropoda. Biosfer: Jurnal Pendidikan Biologi, 9(1), 20-27. https://doi.org/10.21009/biosferjpb.9-1.4

Seika, A. I. G. A. P. A., Kusmariyatni, N., \& Japa, I. G. N. (2017). Pengaruh Model Pembelajaran Talking Stick Berbantuan Media Question Box Terhadap Hasil Belajar Ipa Kelas V. Journal of Education Technology, 1(3), 183. https://doi.org/10.23887/jet.v1i3.12503

Seika Ayuni, I. G. A. P. A., Kusmariyatni, N., \& Japa, I. G. N. (2017). Pengaruh Model Pembelajaran Talking Stick Berbantuan Media Question Box Terhadap Hasil Belajar Ipa Kelas V. Journal of Education Technology, 1(3), 183. https://doi.org/10.23887/jet.v1i3.12503

St, W. Z. (2020). Peningkatan Keterampilan Berbicara melalui Metode Bercerita Siswa Kelas III SD Negeri 1 Beringin Jaya Kecamatan Bumi Raya Kabupaten Morowali. Jurnal Studi Guru Dan Pembelajaran, 3(1), 148-156. https://doi.org/https://doi.org/10.30605/jsgp.3.1.2020.249

Stone, R., Cooper, S., \& Cant, R. (2013). The Score of Peer Learning in Undergraduate Nursing Education: A Systematic Review. ISRN Nursing, 2013(i), 1-10. https://doi.org/10.1155/2013/930901

Suarjani, N. M., Pudjawan, K., \& Suartama, I. K. (2013). Penerapan Metode Pembelajaran Talking Stick Untuk Meningkatkan Keterampilan Berbicara Pada Anak TK Kelompok B Di TK Negeri Pembina Singaraja. Mimbar PGSD Universitas Pendidikan Ganesha, 3(2), 56-67. https://doi.org/http://dx.doi.org/10.23887/paud.v1i1.1534

Sugiantiningsih, I. A., \& Antara, P. A. (2019). Penerapan Model Pembelajaran Talking Stick Berbantuan Media Flash Card Untuk Meningkatkan Kemampuan Berbicara. Jurnal Ilmiah Pendidikan Profesi Guru, 2(3), 298-308. https://doi.org/10.23887/jippg.v2i3.15728

Suhardiana, I. P. A. (2018). Model Pembelajaran Talking Stick Sebagai Pendukung Penguasaan English Vocabulary Pada Anak Usia Dini. Pratama Widya, 3(1), 41-54. https://doi.org/http://dx.doi.org/10.25078/pw.v3i1.704

Sumanto, M. (2018). Pelatihan Pembuatan Media Pembelajaran Seni Keterampilan Bagi Guru-Guru Tk Di Kelurahan Mojolangu Kecamatan Lowokwaru Kota Malang. Jurnal KARINOV, 1 No. 2(2), 1-11. https://doi.org/http://dx.doi.org/10.17977/um045v1i2p\%25p

Sumiyati, E. (2017). Penggunaan Model Pembelajaran Interaktif Berbasis Aktivitas Untuk Meningkatkan Prestasi Belajar Siswa Kelas Vi Pada Pelajaran Pkn Sd Negeri 09 Kabawetan. Jurnal PGSD, 10(2), 6672. https://doi.org/10.33369/pgsd.10.2.66-72

Suparmi, S., Marhaeni, A., \& Artawan, G. (2019). Pengaruh Metode Mind Mapping Terhadap Keterampilan Menulis Ditinjau Dari Kemampuan Verbal Pada Siswa Kelas Iv Sdn 1 Dajan Peken Tabanan. Jurnal 
Pendidikan Dasar Indonesia, 3(1), 12-20.

Suwitri, N. P. D., Ardana, I. K., \& Negara, I. G. A. O. (2013). Pengaruh Pembelajaran Mind Mapping Berbantuan Media Konkret Terhadap Hasil Belajar IPA Siswa Kelas V SD Gugus III Banjar Anyar Kediri. Mimbar PGSD, 1(1). https://doi.org/http://dx.doi.org/10.23887/jjpgsd.v1i1.1251

Syam, N., \& Ramlah, R. (2015). Penerapan Model Pembelajaran Mind Mapping Dalam Meningkatkan Hasil Belajar Pada Mata Pelajaran Ilmu Pengetahuan Sosial Siswa Kelas Iv Sdn 54 Kota Parepare. Publikasi Pendidikan, 5(3). https://doi.org/10.26858/publikan.v5i3.1612

Widyastuti, D. A. (2018). Potret interpersonal communication skill mahasiswa calon konselor. Counsellia: Jurnal Bimbingan Dan Konseling, 8(1), 53. https://doi.org/10.25273/counsellia.v8i1.2027 